\title{
Sissoo, its Pathogenic Constraints and their Management in Nepal: A review
}

\author{
Sachin Timilsina*1, Rajeev Bhattarai ${ }^{2}$, Mahamad Sayab Miya ${ }^{3}$, Deepak Gautam ${ }^{4}$ \\ ${ }^{1,3,4}$ Institute of Forestry, Pokhara Campus, Tribhuvan University, Pokhara, Nepal \\ ${ }^{2}$ School of Forest Resources, College of Natural Sciences, Forestry and Agriculture, University of Maine, \\ Orono, ME 04469, USA \\ ${ }^{4}$ School of Ecology and Nature Conservation, Beijing Forestry University, Beijing, China \\ *Corresponding author: sachintimilsina66@ gmail.com | ORCID: 0000-0002-4749-9289
}

How to cite this paper: Timilsina, S., Bhattarai, R., Miya, M.S. and Gautum, D. (2020). Sissoo, its Pathogenic Constraints and their Management in Nepal: A review. Grassroots Journal of Natural Resources, 3(4): 1-17. Doi:

https://doi.org/10.33002/nr2581.6853.03041

Received: 25 August 2020

Reviewed: 15 September 2020

Provisionally Accepted: 19 September 2020

Revised: 11 October 2020

Finally Accepted: 23 October 2020

Published: 20 December 2020

Copyright $@ 2020$ by author(s)

This work is licensed under the Creative Commons Attribution International License (CC BY 4.0).

http://creativecommons.org/licenses/by/4.0/
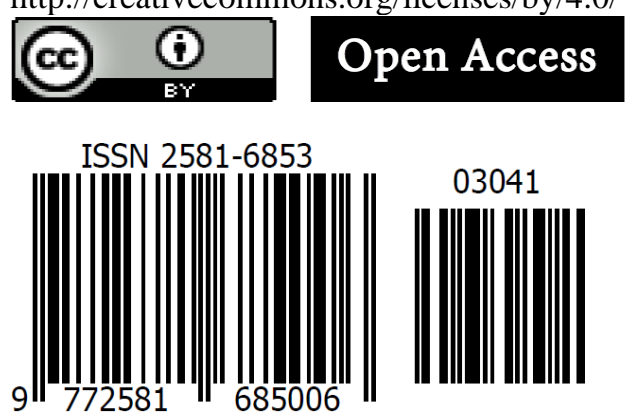

\begin{abstract}
Sissoo (Dalbergia sissoo) is a deciduous tree, native to Nepal and the Indian subcontinent. The tree is traditionally used for making furniture, fodder and herbal medicine. It is also used as shelter-wood, and in conserving soil in degraded areas. This review focuses on the health management practices against pathogenic constraints in sissoo. Literature published till June 2020 was considered to understand the biology of the tree species and associated pathogens apart from understanding the management practices to treat the diseases. Despite the massive significance of this tree, available publications on the pathogenic risks and the strategies to cope with them are unnoticed so far. This article expects to bring together information on sissoo tree's biology, pathogen attacks and its management. Of various fungal diseases in sissoo, this article deals with only two of the fungal diseases, Fusarium solani and Ganoderma lucidum, which cause dieback and root rot in sissoo, respectively. The findings highlighted can further reinforce the current sissoo management and pathogen control strategies and improve its health to augment high quality timber.
\end{abstract}

\section{Keywords}

Dieback; Fusarium; Ganoderma; Root rot; Sissoo 


\section{Introduction}

Sissoo (Dalbergia sissoo) is a multi-purpose tree species grown in the Indian subcontinent (Hossain and Martin, 2013). It is grown throughout the riverine forest of Nepal from the East to West (72 m to $1500 \mathrm{~m}$ altitude) (Parajuli et al., 1999). It grows up to $30 \mathrm{~m}$ in height and $80 \mathrm{~cm}$ in diameter at breast height $(\mathrm{DBH})$ in a suitable geoclimatic condition (Naqvi et al., 2019) occupying welldrained areas near streams and rivers (Shah, Mukhtar and Khan, 2010).

The primary botanical characteristics of sissoo include pinnately compound leaves with alternate pinnation (Bhattacharya, Singh and Ramrakhyani, 2014). The leaflets are broadly ovate, leathery, acuminate, glabrescent and petiolate. Flowers (5-8 $\mathrm{mm}$ long) are scented and whitish to pink in colour. The fruits are in the form of pods, which are oblong, flat, thin and strap-like (4-8 $\mathrm{cm}$ long and $1 \mathrm{~cm}$ wide). Each fruiting pod contains 1-4 kidney-shaped thin, flat, and light brown seeds (Bhattacharya, Singh and Ramrakhyani, 2014). The tree has a long tap-root system and several surface roots producing suckers. Young shoots are downy and dropping while mature tree stems have light brown to dark grey bark up to $2.5 \mathrm{~cm}$ thickness, shed in narrow strips (Kumar and Khurana, 2016). The tree has a spreading oval crown supported by its large upper branches (Sultana et al., 2015).

Commercially, it is used for manufacturing furniture, cabinets, veneers, plywood and musical instruments (Sharma, Singal and Pokhriyal, 2000). Because of its superior quality, color, grain, finishing and durability of hardwood, sissoo is preferred for furniture trade (Bajwa, Javaid and Shah, 2003). As medicines, sissoo bark is used for its anthelmintic property, leaves as an expectorant (muco-active agent), and wood as an antipyretic (fever reducer) and abortifacient (abortion-causing agent) (Shah, Mukhtar and Khan, 2010). In Nepal and India, leaf extracts of sissoo are also used as medicine for gonorrhoea, syphilis, dysentery, sore throat and heart problems (Al-Quran, 2008). The extracts also possess antioxidant property (Yadav et al., 2008). Sissoo trees are also excellent nitrogen fixers, drought-tolerant and effective in recovering sodic land when they are planted in woodlots (Mishra, Sharma and Khan, 2002). However, the ecologically and economically significant sissoo trees, due to different site (salinization, drought, and nutrient depletion) and pathogenic stresses, face a severe problem of reduced productivity, especially in south Asian farmlands (Mishra, Sharma and Khan, 2002; Alauddin and Quiggen, 2008).

The records reveal the exposure of sissoo to several diseases in different environmental settings, causing severe damage to both plantations as well as naturally growing trees. The prevalent diseases mostly include root and foliage damage, caused by phanerogamic parasites and poor soil drainage (causing physiological disorders) (Yousuf, 2002). Several forest pathologists have reported diseases such as powdery mildew, leaf rust, leaf blight, collar rot, wilting, dieback and Ganoderma root rot (Bakshi, 1954; Zakaullah, 1999; Khan, 2000). Wilting (dropping of leaves and branches due to loss of turgidity in plant cells) and dieback (progressive death of twigs and branches from apex to base) diseases in sissoo are still common in recent decades (Shah, Mukhtar and Khan, 2010; Al-Quran, 2008; Ahmad, Khan and Siddiqui, 2013). Dieback disease is mostly caused by Fusarium solani (Rajput et al., 2012) and wilting is its major symptom (Bajwa, Javaid and Shah, 2003). However, wilting in sissoo can be caused by the infection from several pathogens other than F. solani. Further, Ceratocystis fimbriata is believed to be the principal pathogen of sissoo tree causing gummosis (pathological exudation of gum by a plant resulting from fungal or bacterial infection), wilting and chlorosis (yellowing of leaf tissue due to lack of chlorophyll) 
(Poussio et al., 2010). Browne (1968) also reported the serious wilt of sissoo seedlings in nurseries in Pakistan caused by Fusarium oxysporum. Similarly, Ganoderma root rot is another common disease in sissoo (caused by Ganoderma lucidum), which results in wilting of the plant.

The studies on pathogenic stresses of sissoo are significantly lesser in Nepal even though the vast plantation areas are rendered useless time and again (Thapa, 1990; Karki, 1992; Parajuli et al., 1999). However, we can refer to the research carried out in other countries of South Asian region having comparable growing conditions to seek a solution for it. Available literature from Nepal attributes to the vast monoculture practices, deficiency of good seeds, lack of well-equipped institutions and administration for the disease attacks in Terai region (lowland region in Southern Nepal and Northern India) plantation areas (Parajuli et al., 1999; Joshi and Baral, 2000). The main objective of this article is to review the globally available literature on sissoo trees, and management practices to develop a comprehensive health management plan addressing two principal fungal stresses (G. lucidum and F. solani).

\section{Methodology}

Method includes reviewing the published and unpublished research articles from 1954 to 2020 . Google scholar and ResearchGate were the primary databases used for obtaining the literature with keywords "Dalbergia Sissoo", "Sissoo", "Dieback and Wilting", "Sissoo root rot", "Ganoderma lucidum" and "Diseases and pathogens of Sissoo". Finally, 83 published and unpublished items were picked up for review and analysis.

\section{Results and Discussion}

Taxonomy of Sissoo

Table 1 provides details on the Taxonomic classification of sissoo.

Table 1: Taxonomic classification of sissoo

\begin{tabular}{|l|l|}
\hline Kingdom & Plantae \\
\hline Division & Magnoliophyta \\
\hline Phylum & Tracheophyta \\
\hline Class & Magnoliopsida \\
\hline Order & Fabales \\
\hline Family & Fabaceae \\
\hline Genus & Dalbergia \\
\hline Species & sissoo \\
\hline
\end{tabular}

Source: Vasudeva et al., 2009; Sultana et al., 2015

\section{Distribution of Sissoo}

The geographical distribution of sissoo is diverse and dispersed in different zones of tropical Asia, Australia and North America (Thothathri, 1987). It is magnificently grown in Nigeria, Sri Lanka, Kenya, Java, Mauritius, Palestine, South Africa and Northern Zimbabwe (Tewari, 1994). Furthermore, figure 1 shows the worldwide distribution of sissoo trees. 


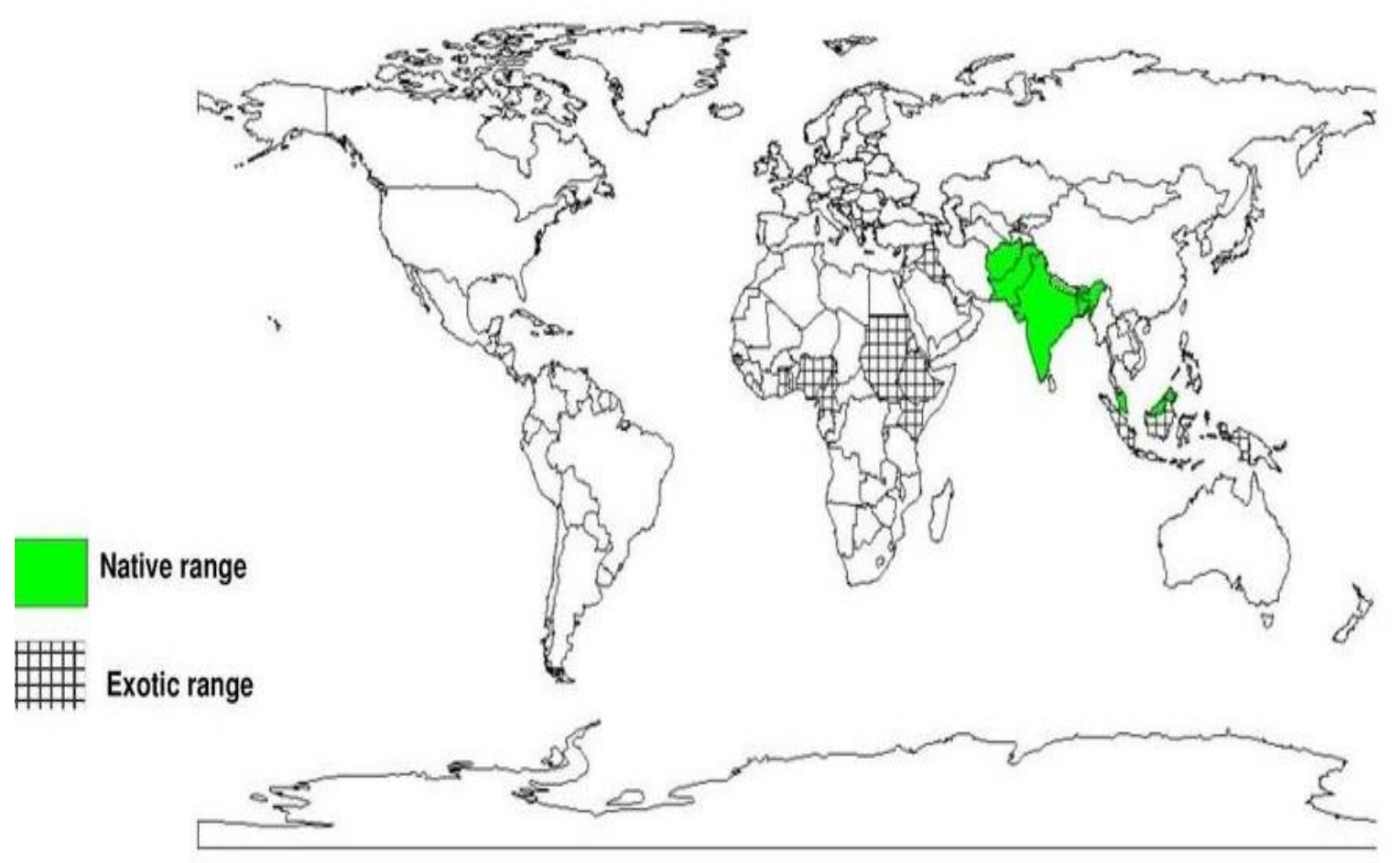

Figure 1: Native and exotic ranges of sissoo (Orwa et al., 2009)

\section{Incidence of the Pathogens}

The fungal pathogens in sissoo have been extracted from different parts of the plant such as leaves barks and roots. Khan et al. (2004) states that Colletotrichum species of leaf blight fungus infects stem and branches of sissoo, while $F$. solani infects root of the plant. Rehman et al. (2012) recorded the pathogens mostly infect roots rather than twigs and barks. The pathogens such as Macrophomina phaseolina (that attacks leaves and barks), F. solani (affects roots, barks and stem), Fusarium oxysporum (affects leaves and barks), Fusarium moniliforme (affects leaves and roots), Rhizoctonia solani (infects sissoo leaves and barks), and Botrytis species (affects roots of sissoo) were recorded from Swabi district of Pakistan. Comparing the incidences in barks, roots and leaves, F. solani causes higher rate of infection in roots (Parveen et al., 2019). Ahmad, Hanan and Gul (2015) reported Botryodiplodia theobromae as the chief causative agent of dieback disease in sissoo in Faisalabad of Pakistan. They further noted that F. oxysporum, F. solani and B. theobromae are concentrated in stem, leaves and the whole plant, respectively. Besides, there are four species of Aspergillus recorded, A. flavus, A. fumigatus, A. japonicus and A. teerius (found in seeds), which are responsible for ceasing the germination of the sissoo seeds (Javaid, Shafique and Bashir, 2010) (Table 2).

Table 2: Fungi isolated from different parts of sissoo

\begin{tabular}{|l|l|l|}
\hline Fungi Isolated & Nature of disease & Plant parts affected \\
\hline Botryodiplodia species & Soil-borne & Roots \\
\hline Cladosporium species & Soil-borne & Seeds, Pods \\
\hline
\end{tabular}




\begin{tabular}{|l|l|l|}
\hline Colletotrichum sissoo & Air borne & Leaves \\
\hline Aspergillus species & Seed-borne & Seeds, Pods \\
\hline Ganoderma species & Wood rot & Heart wood \\
\hline Fusarium solani & Soil-Borne & Roots, Heart wood \\
\hline Slternaria species & Seed-borne & Seeds, Pods \\
\hline Phoma species & Leaf blight & Leaves \\
\hline Maravalia achora & Leaf blight & Leaves \\
\hline Phyllachora dalbergiae & Leaf spot & Leaves \\
\hline Phyllactinia dalbergiae & Powdery mildew & Leaves \\
\hline Uredo sissoo & Leaf rust & Leaves \\
\hline Polyporus species & Wood rot & Heart Wood \\
\hline
\end{tabular}

Source: Manandhar and Shrestha, 2000; Naqvi et al., 2019

\section{Decline and Dieback of Sissoo}

Generally, a decline in sissoo is attributed to the decrease in development, maturation, power and vigour of the plant, whereas complete destruction of the tree crown is considered as dieback (Naqvi et al., 2019). Fungal pathogens including Fusarium solani, Fusarium oxysporum, Phytohpthora cinnamomi, Curvularia lunata, Ganoderma lucidum and Rhizoctonia solani are recognized as causative pathogens for rapid decline and death of sissoo (Ahmad, Khan and Siddiqui, 2013). Rajput et al. (2010) detected ten fungi from different parts of the sissoo tree; and by inoculation they observed that $F$. solani causes higher infections (75\%) compared to other fungi. Similarly, Shakya and Lakhey (2007) also confirmed $F$. solani to be the causal agent for dieback of sissoo in a lab experiment on diseased host samples collected from different parts of Nepal.

Sissoo is under critical risk of dieback disease for last few decades in Pakistan (Ahmad, Khan and Siddiqui, 2013), India (Sharma, Singal and Pokhriyal, 2000), Bangladesh (Tantau et al., 2005) and Nepal (Thapa, 1990), and disease is affecting millions of sissoo trees in these countries (Vogel et $a l ., 2011)$. This disease has been a serious threat to sissoo forest and timber production activities in India, Nepal, Pakistan, Bangladesh and Afghanistan since 1993 (Shukla, 2002). Wilting is the common symptom of decline and dieback (first observed in natural and plantation forest in Uttar Pradesh, India) (Bakhshi, 1954). Wilting takes place when the vessels of a tree get plugged by fungal (F. solani) hypha (Bajwa, Javaid and Shah, 2003; Bakhshi, 1954; Bakhsai and Singh, 1959). About $80 \%$ of sissoo trees in Punjab of Pakistan were reported to be suffering from wilting along the canal bank and roadside areas; however, the trees growing in the agricultural and well-managed lands were less disturbed by wilt and dieback disease (Bajwa and Javaid, 2007).

Both biotic and abiotic stress agents are responsible for the dieback disease hampering the natural physiological activities of plants (Basak, Baksha and Khair, 2003), among which insects and pathogens are biotic stress agents while extreme temperature, drought, and waterlogging conditions are abiotic stress agents (Naz et al., 2015). The sissoo tree weakened by $F$. solani finally dies due to further stresses from the environment and other biotic factors (Javaid, Bajwa and Anjum, 2004). Various secondary factors including insects (termites), fungi (phytophthora), livestock (causing girdling on the tree), human activities (pruning, herbicide spray drift, etc.), and climate change are responsible for the dieback of sissoo (Simpson, 1993; Bajwa, Javaid and Shah, 2003). 
Besides, sissoo dieback is also found to be associated with the tree age (Ahmad et al., 2019), bacteria (Aktar et al., 2016; Valdez et al., 2013) and viruses (Vogel et al., 2011). Acharya and Subedi (2000) conducted a field survey from $28^{\text {th }}$ March to $19^{\text {th }}$ April 2000 to quantify the degree of damages caused by dieback in sissoo in the western region of Nepal where they recorded mortality of over-matured dieback-affected sissoo trees in a short period of time. Tantau et al. (2005) performed $16 \mathrm{~S}$ rDNA sequence analysis ${ }^{1}$ of trees suffering from dieback and found bacteria as a causative agent of dieback disease. They found Pseudomonas bacteria in the samples of severely affected sissoo tree. Recording presence of double stranded RNA and other viral particles in leaf samples of sissoo trees infected with dieback, Vogel et al. (2011) concluded that dieback is caused by viruses too.

\section{Symptoms of Dieback in Sissoo}

Some common symptoms of dieback disease of sissoo trees are dried leaves and branches, alteration in color and wilting of the crown, which finally leads to death of the tree (Tantau et al., 2005). Dieback infected trees also bear the reduced leaf size, lesioned stem (producing gum), change in leaf color (dark green to light green or yellow) and, finally, the entire tree gets defoliated leaving the branches leafless and desiccated from apex to base (Ahmad, Khan and Siddiqui, 2013). Pathogens causing dieback are mostly found in roots of sissoo but sometimes in trunk bases too (Tantau et al., 2005). Symptoms first appear in the crown of the tree and then move downwards, leading to a stag headed condition in the severe stage (Khan, 2000; Bajwa, Javaid and Shah, 2003).

\section{Management of F. solani (fungus causing dieback in Sissoo)}

Billions of sissoo trees have been rendered useless in different parts of South Asia until now due to the dieback and decline disease; still, the practical solution is unavailable (Naqvi et al., 2019). The mitigation approaches adopted for this disease are slightly different in various regions of South Asia with more focus on control measures rather than the preventive measures. However, the awareness generating seminars for the local people besides the technical interventions to control the disease are producing positive results in Pakistan (Javaid, 2008). For any type of disease control, information on the history of disease, frequency of epidemic, prevalent pathogens, resistant host varieties, locality factors, accessibility of labour, and cost would be beneficial before carrying out the intended management activity (Agrios, 2005).

Studies reveal that $F$. solani could be controlled both biologically and chemically. Studies show Trichoderma species to be effective against the growth of $F$. solani due to the production of both antibiotics and extracellular lytic enzymes working against the fungal development (Elad, Chet and Henis, 1982; Basak and Basak, 2011; Banerjee et al., 2020). Trichoderma harzianum releases chitinolytic enzymes that control the development of various pathogenic fungi (Lorito et al., 1993). Further, chitinolytic enzymes produce volatiles that suppress the growth of fungal species and cause vacuolation of its cell, followed by the breakdown of fungal hyphae (Brasier, 1975).

The biological control measures alone might not be the sole solution for this pathogen, where it demands the introduction of chemical inhibitors. In most of the cases in Nepal, studies show the frequent use of Bordeaux mixture (50\% lime $+50 \%$ copper sulphate) paste (Karki et al., 2000;

${ }^{1} 16 \mathrm{~S}$ rDNA sequence analysis is a broadly used technique for the identification of bacteria (Sun et al., 2008). 
Parajuli et al., 1999). To overcome $F$. solani in India, different kinds of fungicides, namely Antracol, Copper Oxychloride, Ridomil Gold, Dithane M-45, Alliete and Topsin-M, were tested against $F$. solani in varying concentrations (Nene and Thapliyal, 1993). Dithane M-45 and Ridomil Gold were most effective against $F$. solani whereas Topsin-M and Alliete showed partial results. Antracol and Copper oxychloride were least efficient in retardation of fungal growth. Similarly, in another study, Ridomil Gold, Dithane M-45, Captan, Bayleton and Benomyl exhibited higher effectiveness against the mycelia growth of $F$. solani in-vitro. In contrast, Alliete showed minimal influence against this fungus, while Benomyl was useful in-vivo only (Rai and Mamatha, 2005). Further, Dennis and Webster (1971) suggested that Carbendazim and Captan have the inhibitory effect on the mycelial growth of $F$. solani. Moreover, Ahmad et al. (1996) reported Vitavax, Bavistin, Dithane M-45 and Benlate to be capable of retarding the growth of mycelia in $F$. solani. Injecting Methyl-2benzi Maidazol carbamate (MBC) (a precipitate) toxicant (derived from benomyl fungicide) is also believed to be effective against sissoo wilting due to its firmness and strength (McWain and Gregory, 1973). Although several chemicals have been tested against $F$. solani, Idrees et al. (2006) claimed no cure for it when the disease prevalence exceeds $25 \%$ in his experiment, which used Topsin-M, and Dithane along with other chemicals (M-45, Trimitox Forte, Score and Derosal) in Pakistan for the control of sissoo dieback disease. The results from the experiments infer the toughness to cease or overturn the advancement of the disease once the symptoms of dieback are onset (Javaid, Bajwa and Anjum, 2004).

\section{Ganoderma Root Rot in Sissoo}

Ganoderma root rot in sissoo is caused by the fungus Ganoderma lucidium (division Basidiomycota). G. lucidum attacks both natural and plantation sissoo forest spreading quickly on light-textured soil as compared to heavy textured; therefore, the trees are swiftly killed in such sites (Bakshi, 1974). Once the tree is infected with this fungus, it attacks the cambium of the tree and interferes with the nutrient and water supply, eventually leading the tree to death (Bhattarai et al., 2020).

Generally, G. lucidum infects broad and small-leaved trees in natural forest (Bakshi, Reddy and Singh, 1976) and sissoo is one of them. G. lucidum (Fr.) Karst. (Dadu chyau in Nepali) has been documented from different parts of Nepal on various substrates like rotten trunks (from Bakhri kharka, north of Pokhara) (Balfour-Browne, 1968), tree trunks (from Lele, Kathmandu) (Singh and Nisha, 1976), and trunk of Rhododendron arboretum and Quercus species (from Manichur, Kathmandu) (Adhikari, 1988). In early 1989, it was reported that G. lucidum was responsible for the mass-mortality (75\% of total) of a ten-year-old sissoo plantation in Teekapur, Kailali District, Nepal (Thapa, 1990; Karki, 1992). The general means of Ganoderma spore introduction in hosts and its life cycle is presented in figure 2. 


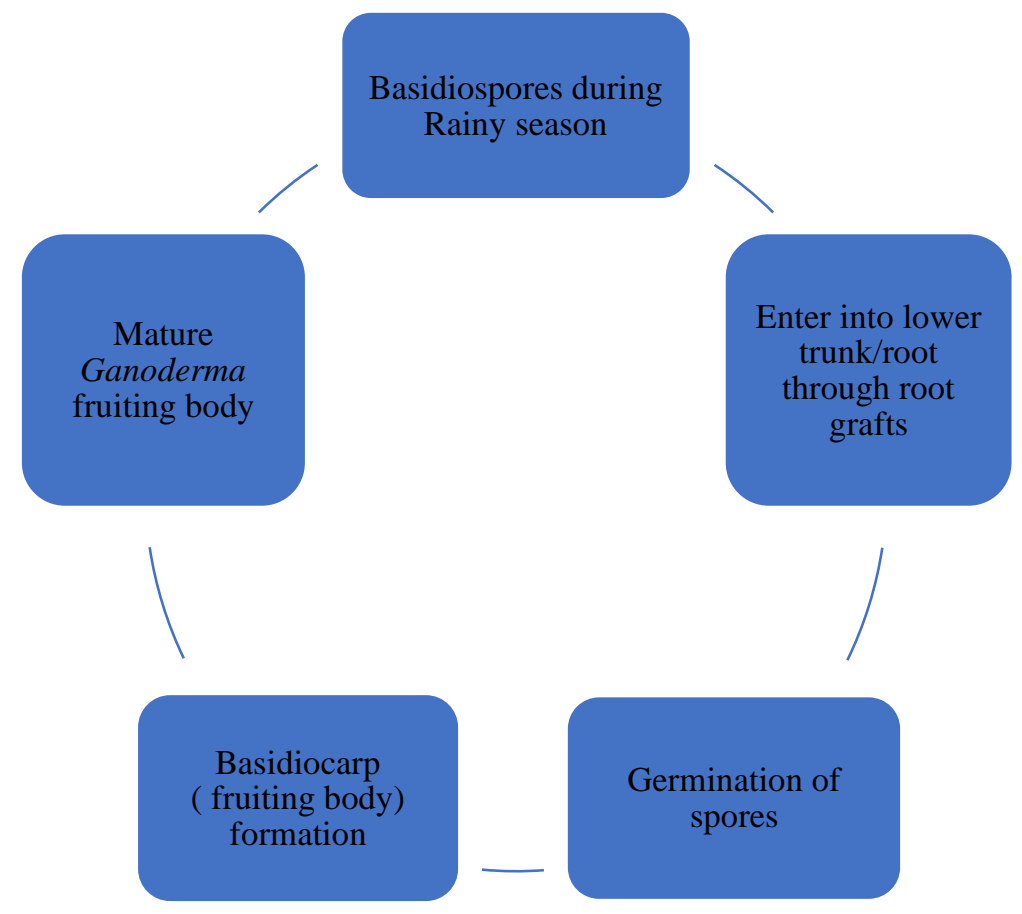

Figure 2: Life cycle of G. lucidum (adopted from Bhattarai et al., 2020).

Signs and Symptoms of G. lucidum

The initial visible sign of infection is the formation of fruiting bodies (description provided in Table 3 and Figure 3), either single or in clusters, on the lower trunk and exposed root areas (Verma, 2014; Bhattarai et al., 2020). However, the appearance of conks (shelf-like fruiting bodies around 14 inches or $35.6 \mathrm{~cm}$ wide) is the final sign after which the disease becomes irreversible (Missouri Botanical Garden, 2012). The basidiocarp (basidium (spore) bearing fruiting body) of Ganoderma is annual, hard, and brittle and appears in the rainy season (Bhattarai et al., 2020). It is originated on a brown stalk, laterally stipitate, and can be observed in the collar or basal region of the tree (Verma, 2014; Zhou et al., 2015). Its upper and lower surfaces are yellowish-brown and white, respectively, and produce a white mycelial mat in between bark and the wood of infected trees (Verma, 2014). In the sissoo tree, G. lucidum infects root through wounded surfaces, damages bark and causes white fibrous rot in the sapwood. This fungus spreads through root contact from treeto-tree, and symptoms start to appear from the third year of plantations (Bakshi et al., 1972). Followed by the infection, the whole tree becomes leafless, branches start dying, and ultimately the tree dies within a few years. Infected trees exhibit a stag-headed condition in the beginning and finally, root and butt rot right before the death (Shah, Mukhtar and Khan, 2010; Bakshi, 1974). Yellowing of leaves, wilting, appearance of undesirable leaves, dead branches, and decay of sapwood are other symptoms of this fungal infection (Shah, Mukhtar and Khan, 2010).

Table 3: Description of Ganoderma lucidum fruiting body

\begin{tabular}{|l|l|}
\hline Scientific name & Ganoderma lucidum \\
\hline Common name & Reishi mushroom \\
\hline Family & Ganodermataceae \\
\hline Colour (mature fruiting body) & Red with white colour pores \\
\hline
\end{tabular}




\begin{tabular}{|l|l|}
\hline Length (mature fruiting body) & $6.4 \mathrm{~cm}$ \\
\hline Width (mature fruiting body) & $3.5 \mathrm{~cm}$ \\
\hline Spore bearing surface under cap & Pores on hymenium \\
\hline Spore diameter (average) & Length: $9.0 \mu \mathrm{m}$, Width: $5.53 \mu \mathrm{m}$ \\
\hline Spore shape & Single-walled, smooth and oblong or spherical \\
\hline Pileus (fruiting body) & Whitish, dry and curved in the margin \\
\hline Texture of the fruiting body & Woody \\
\hline Flesh odour (fruiting body) & Disagreeable \\
\hline Pores colour & White \\
\hline
\end{tabular}

Source: Aminuzzaman and Das, 2016
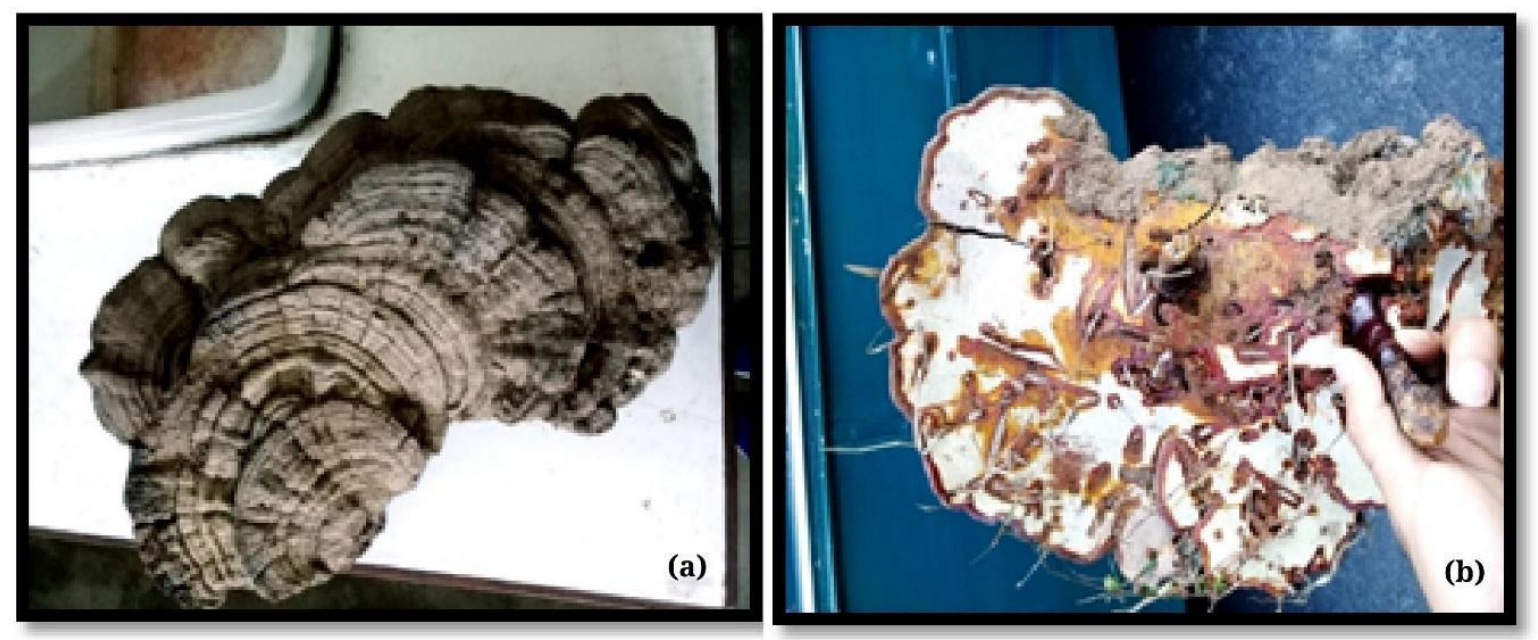

Figure 3: (a) Dorsal view, and (b) Ventral view of the G. lucidum fruiting body

\section{Control Measures of G. lucidum}

Similar to the biological control measures applied for $F$. solani, Trichoderma species themselves are the most effective biocontrol agents for G. lucium reported so far because of their considerable potential on growth reduction of G. lucidum in vitro (Srilakshmi et al., 2001). Among the three species of Trichoderma, T. viride, T. harzainum, and T. pseudokoningii the maximum reduction of fungal growth was showed by $T$. harzianum $(68.5 \%)$ followed by $T$. viridae $(65.7 \%)$ and $T$. pseudokoningii (Nirwan et al., 2016). In plantation, we can directly apply the fungus (available in market under different trade names) on the seed/seedling or in the soil.

In vitro studies performed by Nirwan et al. (2016) on the management of root rot disease (caused by G. lucidum), the fungicides, Bavistin 50\% WP, Mancozeb (Dithane M-45 75\% WP), propiconazole $25 \% \mathrm{EC}$, and Copper oxychloride $50 \% \mathrm{WP}$, were tested at four different concentrations $(0.1 \%, 0.15 \%, 0.2 \%$, and $0.25 \%)$ against the target fungus. Amongst four of them, Bavistin, Mancozeb, and Propiconazole suppressed the fungal growth (100\%) at even the lowest chemical concentration. Chakrabarty, Acharya and Sarma (2013) in their study experimenting on similar fungicides (Calixin (tridemorph), Bavistin, and Mancozeb) experimented in-vitro reported higher strength of Bavistin (100\% inhibition) and Calixin (Tridemorph) (91.3\% inhibition) for 
fungal growth control. The study also compared Bordeaux mixture with Bavistin and claimed to be equally efficient in reducing the growth of G. lucidum. Additionally, Bhattarai et al. (2020) also recommend the use of tridemorph containing fungicides to control the fungus.

\section{Health Management Plan of Sissoo against F. solani and G. lucidum}

The management plan is designed based on the prevalent risk factors and host-pathogens biology. The plan comprises three fundamental working units. The overall management plan strongly emphasizes on the preemptive measures to avoid the disease incidence and later focuses on the implementation of control measures. Figure 4 summarizes the management plan of sissoo in the form of a flow chart.

\section{Preemptive Measures}

These measures are applied before the disease incidence takes place. They help to cope with the risk factors and prevent the disease outbreak. Given that the over-aged sissoo trees are highly susceptible to the fungal attack (Acharya and Subedi, 2000; Ahmad et al., 2019) their removal from the forest stand is highly recommended. The first step before the new plantation to prevent the disease should be the elimination of decayed wooden fragments and fungal fruiting bodies from the last plantation. Disinfecting the nursery beds with any fungicide before sowing sissoo seeds and cuttings should be mandatory. Moreover, focusing on light-textured soil, better drainage conditions, deep planting and irrigation to develop a deep and healthy root system will make sissoo trees less susceptible from $F$. solani and G. lucidum both.

Growing disease-resistant trees is another simple and effective measure to discourage disease incidences. Among several ways of obtaining disease-resistant breeds, quality seeds from breeding seed orchards (BSOs) (stand grown to produce superior seeds) could be considered. Moreover, time to time consultation with the forest department for acquiring improved seeds and seedlings with strict quarantine during their transport from one site to another will also aid in disease control. Besides, promoting mixed plantation of sissoo with resistant varieties like Acacia nilotica, and Morus species should be encouraged since these species are widespread in Nepal. Since the high forest sissoo trees are facing a severe risk of dieback in the South Asian subcontinent (Singh, Yadav and Bhatt, 2011), the cultivators would benefit from adopting vegetative propagation (branch cutting) to mitigate this issue. Taking into account the fact that wounds in the plant body are the entry point for the fungi (Khan et al., 1965), silvicultural practices like pruning and thinning should be strictly followed as suggested by the forestry experts to prevent and treat the wound to discourage the entry of fungi.

\section{Regular Monitoring and Survey of the Signs and Symptoms}

Monitoring is an intermediate step focused on the identification of disease and preventing its spread from the infected to healthy trees. Aim of this approach is to identify the disease as soon as possible from the disease signs and symptoms. During monitoring, observed wounds in roots and trunks should be sealed with rubber latex and grafting wax or treated with fungicides to prevent the fungal infection. The monitoring should be performed in a participative way between the locals and forest technicians, for the better identification of signs and symptoms. In case of unidentified signs and symptoms, fertilization and watering the trees (especially in private or accessible stands) enhance 
the concentration of the nutrients in soil that provides resistance power to the tree against the fungi. Use of farmyard manure (possessing antifungal characteristics) is highly recommended for fertilizing the soil.

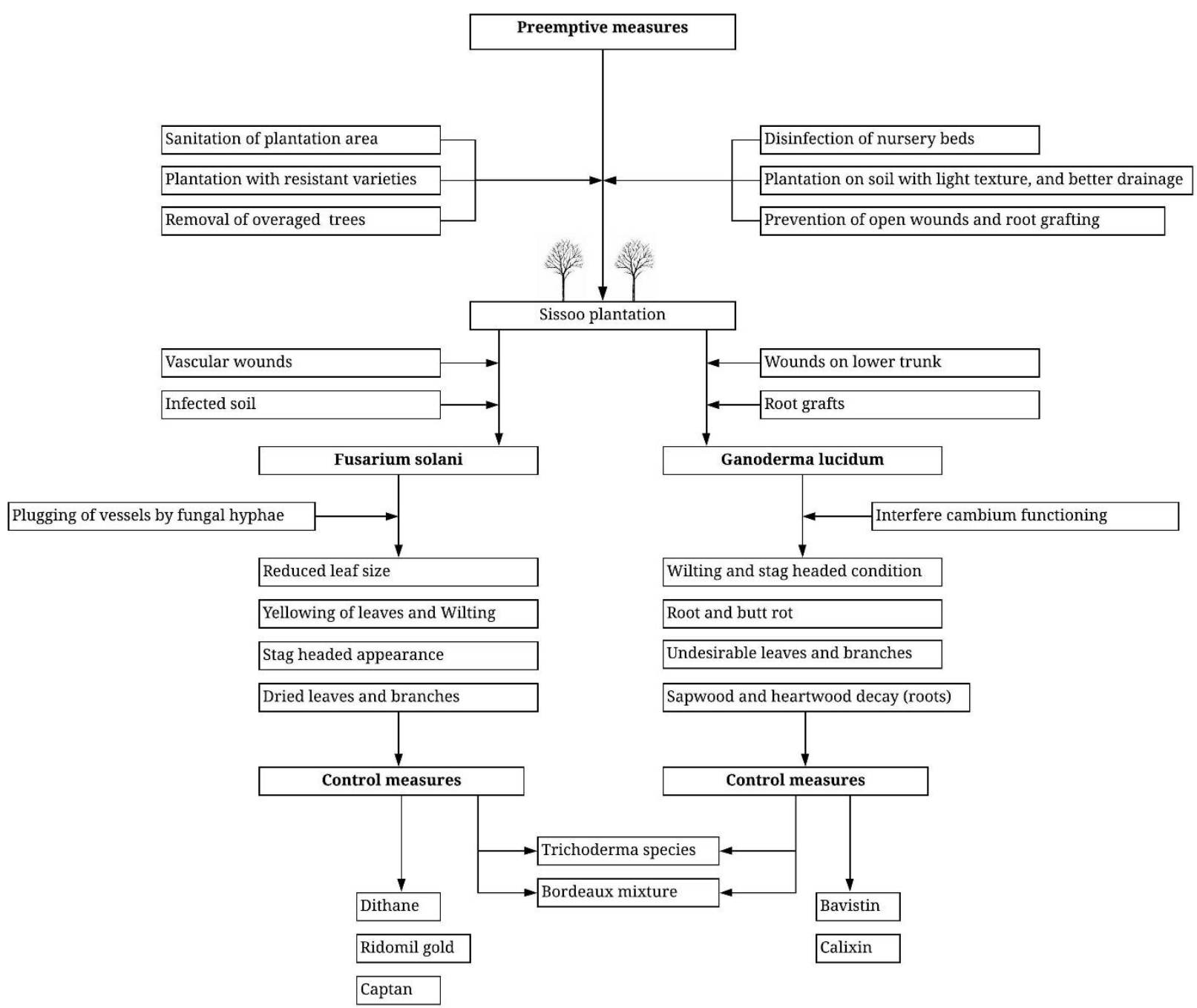

Figure 4: Health management plan of sissoo. The flow chart emphasizes on the causal agents of diseases, their identification, and measures to prevent and control them. Authors conceptualized the flowchart.

\section{Reactive Measures}

This section deals with treatment of the disease to prevent further loss and spread. For treating a diseased tree, first, biological measures to avoid the side effects of chemicals in the environment and human health are recommended. In case the biological methods fail to perform, the adoption of chemical controls is justifiable. Analyzing the adopted control measures against $F$. solani and G. lucidum, test of Trichoderma species as a biological control measure is proposed in Nepal. In case of chemical control measures, wide varieties of chemicals have been experimented against $F$. 
solani so far, but their credibility for use in Nepalese context is uncertain. Still, observing the repetitive success of Dithane M-45, Ridomil gold and Captan in other countries, such chemicals for testing their effectiveness are recommended. However, use of Bordeaux mixture can be introduced as new control measure. Similarly, for G. lucidum, the fungicides, namely Bavistin, Calixin and Bordeaux mixture, have been observed promising.

Furthermore, if the treatment and cure are not possible or none of the treatment methods is proving useful, then extraction and destruction of the diseased component is recommended. The Government of Nepal reported the implementation of one farmer strategy in Nepal to remove dead and dying trees from the site, to inhibit the spread of Fusarium throughout the plantation (DoFRS, 2000). Still, the effectiveness of this strategy is unproven (Webb and Hossain, 2005). However, the best idea is to remove the infected trees immediately after it starts showing the symptoms of dieback to prevent the further spread of $F$. solani and destroy the whole tree along with fruiting bodies to restrict the spread of Ganoderma lucidum.

\section{Conclusion}

Sissoo is a multi-use tree species with a huge traditional and ecological significance especially in the South Asian region; however, Fusarium solani and Ganoderma lucidum are causing the serious problem of dieback and root rot, respectively, in almost all the countries where it grows. The past and current health management practices for sissoo against the pathogenic fungi are heavily relying on the chemical control strategies, which are polluting the environment as well as imparting complexity of use among the cultivators. The health management plan, which encourages the use of fewer chemicals, and more biological and silvicultural control measures, is proposed in this article. Among the chemicals suggested for control, Bordeaux mixture is serving to prevent both the fungi and should be adopted before trying others. The suggested management plan is a blend of strategies for all growing areas of sissoo in Nepal. A trial of the suggested management approach is recommended first on a small scale with possible upscaling upon the success. Therefore, there is abundant scope to use the recommendations given in this article incorporating the policy part for Nepal government. Further, investigations on additional stress agents interfering the growth and development of sissoo should also be taken up in the future.

\section{References}

Acharya, K.P. and Subedi, N. (2000). A survey on the dieback Dalbergia sissoo in Nepal. In: Proceeding of sub-regional seminar on dieback of Sissoo, Dalbergia sissoo Roxb., Kathmandu, 23-26.

Adhikari, M.K. (1988). Polypores (wood-rotting fungi) of Nepal. Banko Janakari, 2(1): 9-20.

Agrios, G.N. (2005). Plant pathology, 5th ed. London, United Kingdom: Elsevier Academic Press.

Ahmad, B.I., Khan, R.A. and Siddiqui, M.T. (2013). Incidence of dieback disease following fungal inoculations of sexually and asexually propagated shisham (Dalbergia sissoo). Forest Pathology, 43(1): 77-82. Doi: https://doi.org/10.1111/efp.12001

Ahmad, I., Atiq, M., Nawaz, M.F., Ahmed, S., Asif, M., Gull, S., Tanvir, M.A., Abdullah, M., Azhar, M.F. and Rajput, N.A. (2019). Prediction of dieback disease of Dalbergia sissoo (Shisham) based upon environmental factors and tree age. Applied Ecology and Environmental Research, 17(3): 6483-6495. 
Ahmad, I., Hanan, A. and Gul, S. (2015). Frequency of mycoflora associated with Shisham (Dalbergia sissoo) decline in district Faisalabad, Pakistan. FUUAST Journal of Biology, 5(2): 225-229.

Ahmad, M., Khan, M.A., Ahmad, F. and Khan, S.M. (1996). Effectiveness of some fungicides on the colony growth of Fusarium oxysporum and $F$. solani associated with potato wilt. Pakistan Journal of phytopathology, 8: 159-161.

Aktar, L., Shamimul-Alam, S.K., Imdadul, H.M., Sarker, R.H. and Saha, M.L. (2016). Bacteria associated with the dieback disease of sissoo trees (Dalbergia sissoo Roxb.) in Bangladesh. Imperial Journal of Interdiciplinary Research (IJIR), 2(12): 1324-1329.

Alauddin, M. and Quiggin, J. (2008). Agricultural intensification, irrigation and the environment in South Asia: Issues and policy options. Ecological Economics, 65(1): 111-124. Doi: https://doi.org/10.1016/j.ecolecon.2007.06.004

Al-Quran, S. (2008). Taxonomical and pharmacological survey of therapeutic plants in Jordan. Journal of Natural Products, 1(1): 10-26.

Aminuzzaman, F.M. and Das, K. (2016). Morphological characterization of polypore macro fungi associated with Dalbergia sissoo collected from Bogra district under social forest region of Bangladesh. Journal of Biology and Nature, 6(4): 199-212.

Bajwa, R. and Javaid, A. (2007). Integrated disease management to control Shisham (Dalbergia sissoo Roxb.) decline in Pakistan. Pakistan Journal of Botany, 39(7): 2651-2656.

Bajwa, R., Javaid, A. and Shah, M.B.M. (2003). Extent of shisham (Dalbergia sissoo Roxb.) decline in Sialkot, Gujranwala, Lahore and Sargodha districts. Mycopath, 1(1-5): 1-5.

Bakhshi, B.K. (1954). Wilt of shisham (Dalbergia sissoo) due to Fusarium solani. Nature, 174: 278-291.

Bakhshi, B.K. and Singh, S.L. (1959). Root disease of Shisahm (Dalbergia sissoo): Inoculation study on wilt. Indian Forester, 85: 415-421.

Bakshi, B.K. (1954). Wilt of shisham (Dalbergia sissoo Roxb.) due to Fusarium solani Sensu. Snyder and Hansen. Nature, 174(4423): 278-280.

Bakshi, B.K. (1974). Control of root disease in plantations in reforested stands (with special reference to Khair, Sissoo, Eucalyptus etc.). Indian Forester, 100(1): 77-78.

Bakshi, B.K., Reddy, M.A.R. and Singh, S. (1976). Ganoderma root rot mortality in khair (Acacia catechu Willd.) in reforested stands. European Journal of Forest Pathology, 6(1): 30-38. Doi: https://doi.org/10.1111/j.1439-0329.1976.tb00502.x

Bakshi, B.K., Reddy, M.A.R., Puri, Y.N. and Singh, S. (1972). Forest Disease Survey (Final Technical Report). Forest Research Institute, Dehradun, India, pp.117.

Balfour-Browne, F.L. (1968). Fungi of recent Nepal expeditions. Ibid. 4: 99-141.

Banerjee, S., Singh, S., Pandey, S., Bhandari, M.S., Pandey, A. and Giri, K. (2020). Biocontrol potential of Pseudomonas azotoformans, Serratia marcescens and Trichoderma virens against Fusarium wilt of Dalbergia sissoo. Forest Pathology, 50(2): 12581. Doi: https://doi.org/10.1111/efp.12581

Basak, A.C. and Basak, S.R. (2011). Biological control of Fusarium solani sp. dalbergiae, the wilt pathogen of Dalbergia sissoo, by Trichoderma viride and T. harzianum. Journal of Tropical Forest Science, 23(4): 460-466. Online: https://www.jstor.org/stable/23617060.

Basak, A.C., Baksha, M.W. and Khair, M.A. (2003). Symptom and extent of damage caused by wilting of Sissoo (Dalbergia sissoo Roxb.) in Bangladesh. Mortality of Sissoo. In: Mortality of Sissoo (Dalbergia sissoo) and Top Dying of Sundri (Heritiera fomes) in Bangladesh (Baksha M.W. ed.), Bangladesh Forest Research Institute, Chittagong, Bangladesh, 39-42. 
Bhattacharya, M., Singh, A. and Ramrakhyani, C. (2014). Dalbergia sissoo: an important medical plant. Journal of Medicinal Plants, 2(2): 76-82.

Bhattarai, R., Sharma, P., Wagle, B., Adhikari, A. and Acharya, S. (2020). Revision and Compilation of Health Management Plan of Khair (Acacia catechu). Grassroots Journal of Natural Resources, 3(1): 15-28. Doi: https://doi.org/10.33002/nr2581.6853.03012

Brasier, C.M. (1975). Stimulation of sex organ formation in phytophthora by antagonistic species of Trichoderma: I. the effect in vitro. New Phytologist, 74(2): 183-194. Doi: https://doi.org/10.1111/j.1469-8137.1975.tb02604.x

Browne, F.G. (1968). Pests and diseases of forest plantation trees: an annotated list of the principal species occurring in the British Commonwealth. London, UK: Oxford University Press.

Chakrabarty, R., Acharya, G.C. and Sarma, T.C. (2013). Management of basal stem rot of arecanut (Areca catechu L.) under assam condition. The Bioscan, 8(4): 1291-1294.

Dennis, C. and Webster, J. (1971). Antagonistic properties of species-groups of Trichoderma: III. Hyphal interaction. Transactions of the British Mycological Society, 57(3): 363-369. Doi: https://doi.org/10.1016/S0007-1536(71)80050-5

DoFRS (Department of Forest Research and Survey) (2000). Study on dieback of Sissoo (Dalbergia sissoo). Internal report, Department of Forest Research and Survey, Ministry of Forest and Soil Conservation, Kathmandu, Nepal

Elad, Y., Chet, I. and Henis, Y. (1982). Degradation of plant pathogenic fungi by Trichoderma harzianum. Canadian Journal of Microbiology, 28(7): 719-725. Doi: https://doi.org/10.1139/m82-110

Hossain, S.M.Y. and Martin, A.R. (2013). Merchantable timber production in Dalbergia sissoo plantations across Bangladesh: regional patterns, management practices and edaphic factors. Journal of Tropical Forest Science, 25(3): 299-309.

Idrees, M., Zaidi, S.S.H., Khan, A.U., Mahmood, A. and Akhtar, A.S. (2006). Studies on organisms associated with shisham dieback and their pathogenicity. In, Third National Seminar on Shisham Dieback, Faisalabad, Pakistan, 29-36.

Javaid, A. (2008). Research on shisham (Dalbergia sissoo Roxb.) Decline in Pakistan: a review. Pakistan Journal of Phytopathology, 20(1): 134-142.

Javaid, A., Bajwa, R. and Anjum, T. (2004). Identification of some more phenotypes of Shisham (Dalbergia sissoo Roxb.) and their response to dieback and wilt diseases. University of the Punjab, Quaid-e-Azam Campus, Lahore, Pakistan, 2(2): 55-59.

Javaid, A., Shafique, G. and Bashir, U. (2010). Mycoflora associated with stored seeds of different varieties of shisham (Dalbergia sissoo Roxb.). Pakistan Journal of Phytopathology, 22(1): 09-12.

Joshi, R.B. and Baral, S.R. (2000). A report on dieback of Dalbergia sisso in Nepal. Department of Forest Research and Survey. Online: http://www.fao.org/3/ae910e/ae910e03.htm

Karki, D., Thapa, H.B., Juwa, G.B., Tuladhar, J., Manandhar, G. and Das, A.N. (2000). Sissoo dieback: its cause and effect on plantation management. Banko Janakari, 10(2): 43-52.

Karki, M. (1992). Tree disease of Nepalese forests: some problems and their control strategies. Banko Jankari, 3: 13-16.

Khan, A.H., Asghar, A.G., Ghulam Rasul, C. and Hamid, A. (1965). Observation on the mortality of shisham (Dalbergia sissoo Roxb.) and other trees in Khanewal plantation. Part I, II and III, Pakistan Journal of Forestry, 6: 109-120, 203-220, and 289-301.

Khan, M.H. (2000) Shisham dieback in Pakistan and remedial measures. In: Proceedings of the sub-regional seminar on Dieback of Sissoo (Dalbergia sissoo), Kathmandu, 45-50. 
Khan, S.H., Idrees, M., Muhammad, F., Mahmood, A. and Zaidi, S.H. (2004). Incidence of shisham (Dalbergia sissoo Roxb.) decline and in vitro response of isolated fungus spp. to various fungicides. International Journal of Agricultural Biology, 6(4): 611-614.

Kumar, N. and Khurana, S.M.P. (2016). Biomanagement of wilting of a valuable timber and medicinal plant of Shisham (Dalbergia sissoo Roxb.)-A review. International Journal of Current Microbiology and Applied Sciences, 5(1): 32-54.

Lorito, M., Harman, G.E., Hayes, C.K., Broadway, R.M., Tronsmo, A., Woo, S.L. and Di Pietro, A. (1993). Chitinolytic enzymes produced by Trichoderma harzianum: antifungal activity of purified endochitinase and chitobiosidase. Phytopathology, 83(3): 302-307.

Manandhar, G. and Shrestha, S.K. (2000). Fungi associated with dieback of Sissoo. In: Proceedings of the sub-regional seminar on Dieback of Sissoo (Dalbergia sissoo), Kathmandu, 27-30.

McWain, P. and Gregory, G.F. (1973). A benomyl-derived fungitoxicant for tree wilt disease control. USDA Forest Service Research Note NE-162, pp. 3.

Mishra, A., Sharma, S.D. and Khan, G.H. (2002). Rehabilitation of degraded sodic lands during a decade of Dalbergia sissoo plantation in Sultanpur district of Uttar Pradesh, India. Land Degradation and Development, 13(5): 375-386. Doi: https://doi.org/10.1002/ldr.511

Missouri Botanical Garden (2012). Ganoderma root rots. Online: https://www.missouribotanicalgarden.org/

Naqvi, S.A.H., Mushtaq, S., Malik, M.T., Ur Rehman, A., Fareed, S. and Zulfiqar, M.A. (2019). Factors leading towards Dalbergia sissoo decline (Syndrome) in Indian sub-continent: A critical review and future research agenda. Pakistan Journal of Agricultural Research, 32(2): 302-316. Doi: http://dx.doi.org/10.17582/journal.pjar/2019/32.2.302.316

Naz, S., Kausar, H., Saleem, F. and Zafarullah, A. (2015). Characterization of abiotic stress genes from different species of eucalyptus. Pakistan Journal of Botany, 47(4): 1217-1223.

Nene, Y.L. and Thapliyal, P.N. (1993). Fungicides in plant disease control. Third edition. New Delhi: Oxford and IBH Publishing, pp. 531.

Nirwan, B., Choudhary, S., Sharma, K. and Singh, S. (2016). In vitro studies on management of root rot disease caused by Ganoderma lucidum in Prosopis cineraria. Current Life Sciences, 2(4): 118-126. Doi: http://dx.doi.org/10.5281/zenodo.166773

Orwa, C., Mutua, A., Kindt, R., Jamnadass, R. and Simons, A. (2009). Agroforestree database: a tree reference and selection guide version 4.0. Online: http://www.worldagroforestry.org/resources/databases/agroforestree

Parajuli, A.V., Bhatta, B., Adhikari, M.K., Tuladhar, J. and Thapa, H.B. (1999). Causal agents responsible for the dieback of Dalbergia sissoo in Nepal's eastern Tarai. Banko Janakari, 9(1): 7-14.

Parveen, G., Zain, S., Rahim, Z. and Rasul, G. (2019). Dieback disease of Dalbergia sissoo trees of some major areas of district Swabi. Pure and Applied Biology (PAB), 8(2): 1157-1162. Doi: http://dx.doi.org/10.19045/bspab.2019.80057

Poussio, G.B., Kazmi, M.R., Akem, C. and Fateh, F.S. (2010). First record of Ceratocystis fimbriata associated with shisham (Dalbergia sissoo) decline in Pakistan. Australasian Plant Disease Notes, 5(1): 63-65.

Rai, V.R. and Mamatha, T. (2005). Seedling diseases of some important forest tree species and their management. In: Diseases and Insects in Forest Nurseries. Proceedings of the 5th Meeting of IUFRO Working Party, Kerela, India, 51-63.

Rajput, N.A., Pathan M.A., Rajput, A.Q., Jiskani, M.M., Lodhi, A.M., Rajput, S.A. and Khaskhali, M.I. (2010). Isolation of fungi associated with shisham trees and their effect on seed germination and seedling mortality. Pakistan Journal of Botany, 42(1): 369-374. 
Rajput, N.A., Pathan, M.A., Lodhi, A.M., Dou, D., Liu, T., Arain, M.S. and Rajer, F.U. (2012). In vitro evaluation of various fungicides against Fusarium solani isolated from Dalbergia sissoo dieback. African Journal of Microbiology Research, 6(27): 5691-5699.

Rehman, A., Sahi, S.T., Khan, M.A. and Mehboob, S. (2012). Fungi Associated With Bark, Twigs and Roots of Declined Shisham (Dalbergia sissoo Roxb.) Trees in Punjab, Pakistan. Pakistan Journal of Phytopathology, 24(2): 152- 158.

Shah, M.H., Mukhtar, I. and Khan, S.N. (2010). Medicinal importance and association of pathological constraints with Dalbergia sissoo. Pakistan Journal of Phytopathology, 22(2): 135-138.

Shakya, D.D. and Lakhey, P.B. (2007). Confirmation of Fusarium solani as the causal agent of dieback of Dalbergia sissoo in Nepal. Plant Pathology, 56(6): 1041-1041.

Sharma, M.K., Singal, R.M. and Pokhriyal, T.C. (2000). Dalbergia sissoo in India. In: Proceedings of the Sub-regional Seminar on Dieback of Sissoo (Dalbergia sissoo), Katmandu, Nepal, 516.

Shukla, A.N. (2002). Mortality of Dalbergia sissoo in India. Indian Forester, 128(11): 1209-1215.

Simpson, P. (1993). The cabbage trees (Cordyline australis) are dying: Investigations of sudden decline in New Zealand. In: Huetti, R. F. and D. Muller-Dombois (eds) Forest Decline in the Atlantic and Pacific Region. Berlin, and Heidelberg: Springer-Verlag, pp.280-292.

Singh, B., Yadav, R. and Bhatt, B.P. (2011). Effects of mother tree ages, different rooting mediums, light conditions and auxin treatments on rooting behaviour of Dalbergia sissoo branch cuttings. Journal of Forestry Research, 22(1): 53-57.

Singh, S.C. and Nisha (1976). A contribution to the parasitic mycoflora of Nepal. Indian Phytopathology, 6: 11-14.

Srilakshmi, P., Thakur, R. P., Prasad, K. S., \& Rao, V. P. (2001). Identification of Trichoderma species and their antagonistic potential against Aspergillus flavus in groundnut. International Arachis Newsletter, 21: 40-43.

Sultana, S., Asif, H.M., Naveed Akhtar, N. and Akhtar, N. (2015). Dalbergia sissoo Roxb: Monograph. International journal of Pharmacognosy, 2(9): 440-443. Doi http://doi.org/10.13040/IJPSR.0975-8232.2(9).440-43

Sun, L., Qiu, F., Zhang, X., Dai, X., Dong, X. and Song, W. (2008). Endophytic bacterial diversity in rice (Oryza sativa L.) roots estimated by $16 \mathrm{~S}$ rDNA sequence analysis. Microbial Ecology, 55(3): 415-424.

Tantau, H., Hoque, M.I., Sarker, R.H. and Mühlbach, H.P. (2005). 16S rDNA Sequence analysis of bacterial isolates from dieback affected sissoo trees (Dalbergia sissoo Roxb.) in Bangladesh. Journal of Phytopathology, 153(9): 517-521. Doi: https://doi.org/10.1111/j.1439-0434.2005.01012.x

Tewari, D.N. (1994). A monograph on Dalbergia sissoo Roxb. Dehradun: International Book Distributors, India, p.202.

Thapa, F. (1990). Dieback threatens Dalbergia sissoo. Farm Forestry News, 3(8).

Thothathri, K. (1987). Taxonomic revision of the tribe Dalbergieae in the Indian subcontinent, Botanical Survey of India, Culcutta, pp 244.

Valdez, N., Karlovsky, P., Dobrindt, L., Hoque, M.I., Sarker, R.H., Tantau, H. and Mühlbach, H.P. (2013). Role of bacteria in dieback disease of Dalbergia sissoo Roxb. Bangladesh Journal of Botany, 42(1): 1-16. Doi: http://doi.org/10.3329/bjb.v42i1.15710

Vasudeva, N., Vats, M., Sharma, S. and Sardana, S. (2009). Chemistry and biological activities of the genus Dalbergia-A review. Pharmacognosy Reviews, 3(6): 307-319. 
Verma, R.K. (2014). Biodiversity and conservation of forest fungi of Central India. In: Microbial Diversity and Biotechnology in Food Security, New Delhi, 543-559.

Vogel, S., Tantau, H., Mielke-Ehret, N., Hoque, M.I., Sarker, R.H., Saha, M.L. and Mühlbach, H.P. (2011). Detection of virus particles and double-stranded RNA in dieback affected Dalbergia sissoo Roxb. from Bangladesh. Bangladesh Journal of Botany, 40(1): 57-65.

Webb, E.L. and Hossain, S.M.Y. (2005). Dalbergia sissoo mortality in Bangladesh plantations: correlations with environmental and management parameters. Forest Ecology and Management, 206 (1-3): 61-69.

Yadav, H., Yadav, M., Jain, S., Bhardwaj, A., Singh, V., Parkash, O. and Marotta, F. (2008). Antimicrobial property of a herbal preparation containing Dalbergia sissoo and Datura stramonium with cow urine against pathogenic bacteria. International Journal of Immunopathology and Pharmacology, 21(4): 1013-1020. Doi: https://doi.org/10.1177\%2F039463200802100427

Yousuf, M. (2002). Cause and treatment of drying trees. Asian Journal of Plant Sciences, 1(4): 499-501.

Zakaullah, C. (1999, September). Shisham decline in Pakistan. In: Proceeding of National conference of Plant Pathology, Faisalabad, Pakistan, 27-29.

Zhou, L.W., Cao, Y., Wu, S.H., Vlasák, J., Li, D.W., Li, M.J. and Dai, Y.C. (2015). Global diversity of the Ganoderma lucidum complex (Ganodermataceae, Polyporales) inferred from morphology and multilocus phylogeny. Phytochemistry, 114: 7-15. 